\title{
Children's Transport Built Environments: A Mixed Methods Study of Associations between Perceived and Objective Measures and Relationships with Parent Licence for Independent Mobility in Auckland, New Zealand
}

\author{
Melody Smith ${ }^{1, * \mathbb{D}}$, Rebecca Amann ${ }^{1}$, Alana Cavadino ${ }^{1}$, Deborah Raphael ${ }^{1}{ }^{1}$, Robin Kearns ${ }^{2}$, \\ Roger Mackett ${ }^{3}{ }^{(0}$, Lisa Mackay ${ }^{4}\left(\mathbb{D}\right.$, Penelope Carroll ${ }^{5}$, Euan Forsyth $\left.{ }^{2}{ }^{(}\right)$, Suzanne Mavoa ${ }^{6}{ }^{\circ}$, \\ Jinfeng Zhao ${ }^{1}\left(\mathbb{D}\right.$, Erika Ikeda ${ }^{4}$ and Karen Witten ${ }^{5}$ (D) \\ 1 School of Nursing, The University of Auckland, Auckland 1142, New Zealand; \\ rama919@aucklanduni.ac.nz (R.A.); a.cavadino@auckland.ac.nz (A.C.); d.raphael@auckland.ac.nz (D.R.); \\ jinfeng.zhao@auckland.ac.nz (J.Z.) \\ 2 School of Environment, The University of Auckland, Auckland 1142, New Zealand; \\ r.kearns@auckland.ac.nz (R.K.); e.forsyth@auckland.ac.nz (E.F.) \\ 3 Department of Civil, Environmental and Geomatic Engineering, University College London, \\ London WC1E 6BT, UK; roger.mackett@ucl.ac.uk \\ 4 Human Potential Centre, Auckland University of Technology, Auckland 1142, New Zealand; \\ Lisa.mackay@aut.ac.nz (L.M.); erika.ikeda@aut.ac.nz (E.I.) \\ 5 Social and Health Outcomes Research and Evaluation (SHORE), Massey University, Auckland 1142, \\ New Zealand; P.A.Carroll@massey.ac.nz (P.C.); k.witten@massey.ac.nz (K.W.) \\ 6 Melbourne School of Population and Global Health, The University of Melbourne, Melbourne 3010, \\ Australia; suzanne.mavoa@unimelb.edu.au \\ * Correspondence: melody.smith@auckland.ac.nz
}

Received: 15 March 2019; Accepted: 13 April 2019; Published: 16 April 2019

check for updates

\begin{abstract}
Children's independent mobility is declining internationally. Parents are the gatekeepers of children's independent mobility. This mixed methods study investigates whether parent perceptions of the neighbourhood environment align with objective measures of the neighbourhood built environment, and how perceived and objective measures relate to parental licence for children's independent mobility. Parents participating in the Neighbourhood for Active Kids study $(n=940)$ answered an open-ended question about what would make their neighbourhoods better for their child's independent mobility, and reported household and child demographics. Objective measures of the neighbourhood built environment were generated using geographic information systems. Content analysis was used to classify and group parent-reported changes required to improve their neigbourhood. Parent-reported needs were then compared with objective neighbourhood built environment measures. Linear mixed modelling examined associations between parental licence for independent mobility and (1) parent neighbourhood perceptions; and (2) objectively assessed neighbourhood built environment features. Parents identified the need for safer traffic environments. No significant differences in parent reported needs were found by objectively assessed characteristics. Differences in odds of reporting needs were observed for a range of socio-demographic characteristics. Parental licence for independent mobility was only associated with a need for safer places to cycle (positive) and objectively assessed cycling infrastructure (negative) in adjusted models. Overall, the study findings indicate the importance of safer traffic environments for children's independent mobility.
\end{abstract}

Keywords: traffic safety; walking; cycling; infrastructure; active travel; active transport 


\section{Introduction}

Physical activity is fundamental to optimal growth, development, and health in children. It is recommended that children and youth aged 5-17 years should participate in at least 60 minutes of moderate-to-vigorous intensity physical activity (MVPA) daily to gain important benefits for their musculoskeletal, cardiovascular, neuromuscular, metabolic, and mental health and development [1]. Yet physical activity levels are low globally [2], including in New Zealand, where a third of children and youth are insufficiently active for health [3].

\subsection{Children's Independent Mobility}

Children's independent mobility can provide important opportunities for children's physical activity accumulation. Independent mobility was first defined in the early 1990s as having the freedom to travel to destinations or engage in outdoor play without adult supervision [4]. Since that time, numerous definitions, associated metrics, and methods (e.g., parent vs. child reports) have been employed [5-7]. For the most part, literature has focused on parental licence for independent mobility, capturing a range of 'licences' to be independent outside the home environment. To a lesser extent, actualized independent mobility has also been explored, with a dominant focus on active travel (e.g., walking, scootering, or cycling) to school or neighbourhood destinations without adult accompaniment. Irrespective of the metric used, a growing evidence base has consistently demonstrated links between independent mobility and active travel to school [8], objectively-assessed physical activity [9-12], and less sedentary behaviour [12].

Independent mobility also plays an unparalleled role in contributing to children's development of social, cognitive, and spatial processing skills and enhanced environmental awareness. Children who travel and play freely in their neighbourhood socialise more frequently with their peers and adults [13-15] and develop a sense of belonging to their community [16] which is important for developing social skills and a sense of identity. Cognitive and psychological development is promoted through spatial awareness and processing [17], learning about risk and its management [13], and engagement with the natural and physical environment $[13,14,18,19]$.

Despite its benefits, independent mobility has been declining globally over the past several decades $[4,20,21]$. By way of example, in Australia, repeated cross-sectional studies indicate the proportion of children travelling home from school independently halved from $68 \%$ in 1991 to $31 \%$ in 2012 [20]. Longitudinal data on independent mobility in the New Zealand context are not available. Looking at active travel in general (irrespective of accompaniment) the average time children spent in active travel modes decreased from 130 minutes per week to 72 minutes per week in the two decades prior to 2011. Latest household travel statistics show $70 \%$ of travel time for children is spent as a car passenger, and $10 \%$ is spent in active travel modes [20]. Less than half of New Zealand youth actively travel to school [3]. Accordingly, there has been increasing interest in understanding factors related to children's active travel in general as well as their independent mobility.

\subsection{Factors Associated with Children's Independent Mobility}

A socio-ecological perspective is helpful to understand the complexity of children's independent mobility [6,22]. In particular, the systems model proposed by Badland and colleagues [23] provides a robust framework for understanding factors related to children's independent mobility. The model encompasses policy and societal norms, as well as factors at the individual and neighbourhood level, which are described briefly below.

\subsubsection{Child and Household Characteristics}

Parental licence for their child's independent mobility is strongly related to children's actualised independent mobility [24]. Parents are the 'gatekeepers' who determine the travel mode of their children and the degree of freedom they have to independently move in the neighbourhood $[6,25]$. 
Although children seek to influence their mobility licence [26], parents' views are invariably stronger than children's in determining independent mobility [27-29].

Individual factors that are associated with children moving independently in their environment include age and sex. Children who are older, especially after 12 years of age, are more likely to have licence from their parents to engage in independent mobility [9,24,30-32]. Many studies indicate that boys have higher rates of independent mobility compared to girls and tend to gain mobility licence earlier than girls $[9,32,33]$. This difference could be due to the higher parental fear of danger from strangers for girls $[34,35]$.

More broadly, household and family factors such as car ownership, having older siblings [36], competing family schedules and trip chaining [37], and neighbourhood self-selection (i.e., a preference for residing in an environment that is characterized as being more or less walkable) [38-40] may also play important roles in actualizing children's independent mobility.

\subsubsection{Parental Neighbourhood Perceptions}

Parents' perceptions of the neighbourhood environment are associated with whether or not they grant their children independent mobility licence [41]. Parents who view their neighbourhood as safe are more inclined to encourage their children to be physically active outdoors [42]. Perceived safety of the neighbourhood environment may be an especially important indicator for parental licence for independent mobility [30,43], particularly regarding traffic safety and "stranger danger" [35,44]. If parents perceive their neighbourhoods as unsafe they are less likely to allow their children to be independent [45]. Conversely, a positive parental perception of safety from crime in the neighbourhood is associated with greater mobility licence [30,32]. "Stranger danger" has been noted as a concern for parents and has been linked to limited licence for independent mobility $[9,34,35,46]$. On the other hand, social interactions with neighbours [47] and social cohesion and trust [31,32,48] could contribute to creating a neighbourhood that 'looks out for children' and thus encourages independent mobility.

Safety from traffic is a key priority for parents [24,49]. Numerous studies have shown that parental fear of traffic danger is associated with limiting children's independent mobility licence $[21,32,35,36,45,50,51]$. Wolfe and McDonald [32] concluded that parents who had a positive view of traffic safety in their neighbourhood were more likely to grant their children licence for independent mobility. Parents who lived on busy roads [51], who had concerns about high traffic volumes [32], or who lived in less urbanised areas [35] had more traffic safety concerns and their children had less independent mobility. On the other hand, safe road crossings were associated with increased independent mobility of boys in a study of Australian children [51].

Moving beyond neighbourhood safety, a number of built environment features, as perceived by parents, have been related to independent active travel and physical activity of children [28]. Specifically, perceived accessibility to destinations, high land use mix, short distance to school, residential density, and well-maintained walking and cycling infrastructure have all been positively associated with children's independent active travel.

\subsubsection{Objective Measures of the Environment}

The objectively-assessed built environment has also been significantly associated with children's independent mobility [51]. Sharmin and Kamruzzaman [52] argue that changes in children's independent mobility are related to the built environment context (e.g., distance to destination and availability of facilities), urban structure (e.g., urban vs. suburban) or urban form alterations (e.g., intersection density, traffic safety infrastructure). However, to date the evidence remains sparse and inconsistent, thus this section also includes some relevant literature on active travel and physical activity.

Street connectivity has been positively associated with active travel $[53,54]$ and independent mobility [55] in some studies. Conversely, there is also evidence that culs-de-sac (dead end streets) are strongly associated with independent mobility [52]. To some extent, this may be a function of the metric of independent mobility used. For example, where independent active travel is the focus, 
street connectivity would be expected to have a significant role in understanding independent mobility. Conversely, where independent play is of interest, prevalence of neighbourhood culs-de-sac in which to play may be of greater importance. Linked with street connectivity, accessibility to destinations such as schools, parks, and other local settings has been positively associated with active travel and independent mobility [45,54]. Villanueva and colleagues [51] concluded that, in addition to the proximity of destinations, the aesthetics and appeal of destinations are also important features of the built environment that facilitate independent mobility.

Studies in Portugal have shown that when comparing rural and urban areas, increased urbanisation leads to decreased independent mobility of children [24,35]. On the other hand, a meta-analysis by Sharmin and Kamruzzaman [52] concluded that urban-suburban residential location type, and a higher proportion of commercial and residential land use are positively associated with children's independent mobility. To some extent these mismatches may be because these broad environmental measures are not sufficiently fine-grained or population-specific to be relevant to parental decision-making around their child's independent mobility. The field is advancing, however, with examples being the development of new child-specific measures for walkability [56] and destination accessibility [57].

There is also some uncertainty and inconsistency about how objective built environment measures and parent perceptions of the built environment relate, especially in regard to traffic safety. Carver and colleagues [27] identified that there is vagueness as to whether the neighbourhood traffic safety perceptions of parents impact children's physical activity more than objective road safety measures. To date, this has not been clear. Marzi and colleagues [41] concluded in their systematic review that parents' perception of neighbourhood, including that of traffic safety, have a greater impact on children's independent mobility than related built environmental measures. In contrast, Uys and colleagues' study in South Africa concluded that the objective built environment was more strongly associated with out-of-school physical activity of children [58].

\subsection{Study Aim and Objectives}

It is likely that both objective and perceived environmental factors are important in understanding children's independent mobility. Hence, how they relate to each other and with parental licence for independent mobility needs to be better understood to guide and inform future research and practice. The overall aim of this study was to provide new knowledge about factors associated with parental licence for children's independent mobility. Study objectives were: (1) to identify key factors of importance from parent perspectives that would support children's independent neighbourhood active travel, (2) to contextualise parent perceptions in relation to objectively assessed variables around the individual household address, and (3) to determine associations between parental licence for independent mobility and objective neighbourhood built environment measures and parent-reported needs.

\section{Materials and Methods}

\subsection{Protocol and Study Context}

Neighbourhoods for Active Kids was a cross-sectional study of children residing in Auckland, New Zealand. Auckland is New Zealand's largest city with a population of 1.4 million people, a third of New Zealand's total population [59]. The urban landscape of Auckland is comprised largely of suburban neighbourhoods, however there is a move to more compact city housing due to pressures of increasing population and lack of affordable housing [60].

The full study methods are described elsewhere [61]. In brief, addresses of all intermediate schools (junior high school, years 7-8, approximate ages 10-13) in Auckland were geocoded and child-specific measures of walkability [56] and destination accessibility [57] generated for each school. A matrix of walkability, destination accessibility, and school decile (a measure of area-level socioeconomic status [62]) was then used to select schools for invitation, with the aim of ensuring heterogeneity in these 
factors across the study neighbourhoods. Ensuring heterogeneity in geographic location (north, south, east, west, and central Auckland) was also prioritised. For each intermediate school, a contributing primary school (elementary school, years 1-6, approximate ages 5-11 years) was also invited to participate in the study, resulting in a primary-intermediate school dyad in each neighbourhood.

Either Principal or Board of Trustees (governing body of school) consent for their school to participate was required before initiating participant recruitment. Research team members visited each school to explain the study protocols to teachers and students, and deliver child and parent information sheets, child assent forms, and parent/caregiver consent forms for their child and themselves to participate. Those interested in participating were asked to return the signed forms to the school within two weeks (during which time children and their families were invited to ask the research team any questions they had about the study). A signed assent form and signed parent/caregiver consent form were required for a child to participate in the study.

Researchers visited schools during school time to undertake an online participatory mapping survey to capture children's neighbourhood use and perceptions, measure school routes and perceptions of the school route, and capture measures of food purchasing and consumption of unhealthy foods. Height, weight, and waist circumference were measured by trained researchers at this time and children were provided with an accelerometer on a belt and instructions on how to wear the units for the next seven days. Post collection of the accelerometers, a computer-aided telephone interview (CATI) was conducted with parents/caregivers of participating children. The CATI collected sociodemographic information about the child and household, parent neighbourhood perceptions, licence for their child's independent mobility, and reports of their child's activity and nutrition behaviours. For each school, a face-to-face (or telephone-based) semi-structured interview was conducted with the school Principal or delegate to capture contextual information about supports for active travel to school and related policies and initiatives. Objective measures of the built environment for physical activity and nutrition were generated around the home neighbourhood environment, school neighbourhood environment [63], school route [8,64], and home-school neighbourhood [65]. Measures specific to the current study are described below.

Data were collected between February 2015 and December 2016. Ethical approval to conduct the study was provided by the host institution ethics committees (AUTEC, 14/263, 3 September 2014; MUHECN 3 September 2014; UAHPEC 9 September 2014).

\subsection{Measures}

\subsubsection{Socio-Demographic Information}

Parents reported on the biological sex (male, female) of their child and main ethnic group in the CATI survey. Ethnicity variables were adapted to combine 'Middle Eastern/Latin America/African' $(n=17)$ 'other' $(n=4)$, and 'not stated' $(n=158)$ due to low frequencies. School level (primary, intermediate) was recorded during the school-based data collection and used as a proxy for age. Parents were asked how many working cars they had available to them in their household. Area-level socio-economic status was determined using the NZDep2013, an index of deprivation comprising Census-derived measures of income, housing tenure, employment, educational qualifications, family structure, household crowding, access to transport, and communications at the meshblock level (smallest Census-area unit) [66]. Deciles were aggregated into categories of low deprivation (decile 1-3), medium deprivation (decile 4-7), and high deprivation (decile 8-10).

\subsubsection{Independent Mobility Licence}

Licence for independent mobility was assessed using six items from the Policy Studies Institute study of children's independent mobility [21]. Parents were asked whether their child was allowed to travel home from school alone, cross main roads on their own, cycle on main roads alone, go out alone after dark, and go on local public transport on their own. Response options were: always, often, 
sometimes, and never. Parents were also asked whether their child was usually taken or allowed to go alone to places other than school that were within walking distance. Response options were: usually goes alone, varies, and usually taken. All six items were considered in principal components analysis to generate a measure of independent mobility licence. Bartlett's test of sphericity $(p<0.001)$, and the Kaiser-Meyer-Olkin measure of sampling adequacy (0.697) were deemed acceptable. One component was extracted which explained $32.5 \%$ of the variance. A higher score indicated higher licence for independent mobility.

\subsubsection{Parent-Reported Needs}

Parents were asked "What would make your neighbourhood a better place for (Child Name) to walk, bike or scooter by (Himself/Herself)?" Responses were open-ended and parents could mention more than one factor, or choose not to respond.

\subsubsection{Objectively-Assessed Neighbourhood Built Environment Features}

Objective measures were calculated in ArcMap 10.5 (Environmental Systems Research Institute, Redlands, CA, USA) using an 800 m pedestrian street network buffer around each child participant's residential address only. Within the pedestrian network, all motorways and state highway segments were removed to best reflect the pedestrian environment. Unless otherwise specified, spatial data were sourced from the Auckland Council, via the University of Auckland's GeoData Hub database.

Ratio of High- to Low-Speed Roads

Traffic speed exposure was measured as the ratio of high speed ( $>60 \mathrm{~km} /$ hour) road length (HSRL) to low speed ( $<60 \mathrm{~km} /$ hour) road lengths (LSRL) within the neighbourhood boundary [56]. The ratio was calculated as HSRL/LSRL, with a higher ratio indicating a greater number of high-speed roads relative to low-speed roads, and thus greater exposure to vehicular traffic.

Number of Signalised Crossings

Data on pedestrian crossings at controlled intersections (i.e., with a crossing light) were downloaded from Auckland Transport's Open GIS Data platform (https://data-atgis.opendata.arcgis.com/). A spatial join between each neighbourhood buffer and the pedestrian crossing points was implemented, with the sum count of points intersecting each buffer returned.

Ratio of Cycle Path Lengths to Road Lengths

Data for Auckland's cycle lane network were drawn from Auckland Transport's Open GIS Data platform (https://data-atgis.opendata.arcgis.com/). Total cycle lane length (CLL; km) within the neighbourhood buffer was divided by all road lengths (ARL; km), regardless of speed limits to generate a ratio of CLL/ARL, where a higher ratio indicates more cycle lane availability relative to roads.

Pedestrian Network Connectivity (PedShed)

PedShed was measured as the ratio of reachable pedestrian network area (network buffer area; NBA) to the maximum possible area (Euclidean buffer area; EBA) within a given distance of each participant's residence [56]. The NBA was derived using the pedestrian street network buffer, and the EBA via a Euclidian buffering of the residence point. The pedestrian network connectivity variable was calculated as NBA/EBA, with a higher ratio indicating that a greater proportion of the maximum possible distance can be reached through the pedestrian network and, therefore, a more connected pedestrian network. 


\subsection{Data Analysis}

\subsubsection{Objective 1}

Content analysis was performed on parent responses to the CATI question "What would make your neighbourhood a better place for (Child Name) to walk, bike or scooter by (Himself/Herself)?" The lead author undertook initial coding with $40 \%$ of responses to develop a coding framework for key topics and subtopics (saturation was achieved). Deborah Raphael then independently coded all responses using the framework. Finally, the lead author randomly cross-checked $20 \%$ of the full coded dataset. Any disagreements were resolved, and decisions made from this process were used to determine the final coding framework used to code the data. Descriptive statistics for whether or not a subtopic was mentioned by parents were calculated. These were summed to calculate overall frequency of key topics being reported by parents.

IBM SPSS Statistics 24 (IBM Corp, Armonk, NY, USA) was used for all descriptive and inferential analyses. From the content analysis, four topics were identified (based on ranking first and secondly on availability of related objective measures) and recalculated as binary outcomes (i.e., whether parent had reported the topic or not).

\subsubsection{Objective 2}

Mixed effects logistic regression modelling was employed to examine whether there were any significant differences in parent-reported needs by their corresponding objectively-assessed neighbourhood features (outlined in Table 1). All models were adjusted for school level, sex of child, child ethnicity, and deprivation, with neighbourhood included as a random effect. All ratio measures were reclassified into binary variables using the median value to classify variables as low or high [56]. A $p$-value threshold of 0.05 was used to determine statistical significance.

Table 1. Parent reported need and corresponding objective measure of the neighbourhood built environment.

\begin{tabular}{lll}
\hline $\begin{array}{l}\text { Parent-Reported } \\
\text { Needs }\end{array}$ & $\begin{array}{l}\text { Objectively-Assessed } \\
\text { Neighbourhood Features }\end{array}$ & $\begin{array}{l}\text { Key Considerations Regarding Making Direct } \\
\text { Comparisons }\end{array}$ \\
\hline $\begin{array}{l}\text { Less, slower, and safer } \\
\text { traffic }\end{array}$ & $\begin{array}{l}\text { Ratio of high to low speed } \\
\text { roads }\end{array}$ & $\begin{array}{l}\text { Objective measure provides an estimate only of } \\
\text { traffic safety based on road hierarchy (and does not } \\
\text { account for actual driver behavior irrespective of } \\
\text { regulatory environment) parent-reported traffic } \\
\text { safety needs included a broad range of strategies to } \\
\text { reduce speeds and volume of traffic }\end{array}$ \\
\hline $\begin{array}{l}\text { More and safer } \\
\text { crossings }\end{array}$ & $\begin{array}{l}\text { Number of signalised } \\
\text { crossings }\end{array}$ & $\begin{array}{l}\text { Objective measure only takes signalled crossings into } \\
\text { account; parent-reported needs included comments } \\
\text { about non-signalled crossings }\end{array}$ \\
\hline $\begin{array}{l}\text { Safer and designated } \\
\text { cycle lanes }\end{array}$ & $\begin{array}{l}\text { Ratio of cycle path lengths } \\
\text { to road lengths }\end{array}$ & $\begin{array}{l}\text { Objective measure is limited to data available for the } \\
\text { cycle network; parent-reported needs included bike } \\
\text { paths and also the quality of places to cycle safely }\end{array}$ \\
\hline & & $\begin{array}{l}\text { Objective measure provides an indication of the } \\
\text { relative prevalence of places to walk only; } \\
\text { parent-reported needs noted additional } \\
\text { considerations such as wider and better-maintained } \\
\text { footpaths }\end{array}$ \\
$\begin{array}{l}\text { More and better } \\
\text { walking paths }\end{array}$ & PedShed &
\end{tabular}

\subsubsection{Objective 3}

Differences in parental licence for independent mobility were tested for socio-demographic variables using Mann-Whitney U Tests (for sex and school level) and Kruskal-Wallis H Test (for ethnicity and deprivation). Non-parametric tests were used due to non-normal distribution of 
independent mobility licence. Mixed-effects linear models were used to examine relationships with parental licence for their child's independent mobility, including the corresponding perceived and objective measures simultaneously in each model. Sex of child, school level, child ethnicity, and deprivation were all included as fixed effects and neighbourhood was included as a random effect. Interactions between objective and perceived measures were also tested. A $p$-value threshold of 0.05 was used to determine statistical significance.

\section{Results}

Overall, 19 schools across 9 neighbourhoods in Auckland participated in the study. In total, 940 parents participated in the study, providing information about their household, child, and neighbourhood perceptions. Nine cases were eliminated from the analysis due to missing data, yielding a final sample of 931 parents.

\subsection{Objective 1: Parent-Reported Needs}

Parents' responses to the question "What would make your neighbourhood a better place for (Child Name) to walk, bike or scooter by (Himself/Herself)?" fell broadly under nine key areas as outlined in Table 2. A majority of parents (88.1\%) thought there were physical and social environmental aspects that could make their neighbourhood better for their children to be able to walk, cycle, and scooter around. Three percent of parents made positive comments about their neighbourhoods such as:

"I feel that this area is very community focused and it feels quite safe and feels quite child friendly."

Over half of parents (50.3\%) mentioned a need for a safer transport environment (less, slower, and safer traffic; and having safe places to cross, cycle, and walk), with the greatest need being less, slower, and safer traffic (19.9\%). Specifically, parents consistently noted a need for the following:

Slower and safer drivers, for example: "If people keep to the speed limit it would make me feel safer"

Less traffic: "The road traffic is busy and too hard for the kids to use."

more traffic-calming infrastructure: "More speed bumps and more signs near the schools so people can see them and slow down."

Lower speed limits: "Lower speed limits or speed bumps around the area as the people tend to speed down the road and there are a lot of kids in the area that play near the roads."

Signage such as "kids around" to slow traffic and encourage safe driver behaviour: "More caution signs on $[\mathrm{X}]$ Road where we live as the traffic whizzes through ... More caution signs in the hope that people will pay attention to these signs."

Safer places to cross: "More pedestrian crossings on the roads as cars speed around the area" Safer places to cycle: "I'd like to see a dedicated cycle lanes attached to the footpaths that link up to the school."

Safer places to walk: "Decent footpaths as we have no footpaths on our side of the road and so this is a big deterrent. Also cycle ways would be great as in the bays here we have narrow winding roads."

The social environment of the neighbourhood was also significant for parents. Twelve percent of parents reported that safety from others (in particular reduced sense of "stranger danger", increased community surveillance, reduced drug and gang related crimes, fewer roaming dogs and less bullying from youth) would make their neighbourhood better. A more connected community and having more people 'out and about' in their neighbourhood was considered important by $3.5 \%$ of the parents, for example: 
"I guess if we all get together as a neighbourhood and get to know each other very well then we could all look out for each other's kids and we would get to trust each other."

Table 2. Descriptive statistics for key topics derived from parent responses to the question "What would make your neighbourhood a better place for (Child Name) to walk, bike or scooter by (Himself/Herself)?" $(n=931)$.

\begin{tabular}{|c|c|c|}
\hline Topic and Subtopics & $n^{\mathrm{a}}$ & $\%^{a}$ \\
\hline Safety from traffic: Less, slower, and safer traffic & 185 & 19.9 \\
\hline Less busy traffic & 65 & 7.0 \\
\hline Slower speeds & 56 & 6.0 \\
\hline Traffic calming infrastructure (e.g., humps) & 38 & 4.1 \\
\hline Lowering speed limits & 37 & 4.0 \\
\hline Reducing dangerous driving & 34 & 3.7 \\
\hline Improving traffic safety in general & 19 & 2.0 \\
\hline Signage to slow traffic (e.g., "kids around", "slow down") & 6 & 0.6 \\
\hline Safety from traffic: More and safer crossings & 125 & 13.4 \\
\hline More and safer pedestrian crossings & 121 & 13.0 \\
\hline Lights at pedestrian crossings & 4 & 0.4 \\
\hline Supervised crossings & 1 & 0.1 \\
\hline Safety from traffic: Safer and designated cycle lanes & 91 & 9.8 \\
\hline Cycle lanes-designated, away from road, on footpaths & 66 & 7.1 \\
\hline Bike tracks and paths & 26 & 2.8 \\
\hline Safety from traffic: More and better walking paths & 67 & 7.2 \\
\hline Safety from others & 112 & 12.0 \\
\hline Reduced "stranger danger" & 50 & 5.4 \\
\hline Community surveillance & 43 & 4.6 \\
\hline Reduced crime (drugs and gang activity) & 19 & 2.0 \\
\hline Fewer roaming dogs & 12 & 1.3 \\
\hline Reduced perceived danger from others especially youth & 9 & 1.0 \\
\hline Less bullying & 4 & 0.4 \\
\hline More and better destinations & 37 & 4.0 \\
\hline More destinations in the neighbourhood & 23 & 2.5 \\
\hline More and better facilities at the destinations & 16 & 1.7 \\
\hline Better social environment & 33 & 3.5 \\
\hline More connected community & 25 & 2.7 \\
\hline More children/people out and about & 9 & 1.0 \\
\hline Others & 232 & 24.9 \\
\hline Better street lighting & 56 & 6.0 \\
\hline Child too young & 45 & 4.8 \\
\hline Nothing & 38 & 4.1 \\
\hline Positive Comments & 31 & 3.3 \\
\hline Less hilly & 14 & 1.5 \\
\hline Safer neighbourhood & 12 & 1.3 \\
\hline Other & 10 & 1.1 \\
\hline More public transport and school buses & 9 & 1.0 \\
\hline
\end{tabular}


Table 2. Cont.

\begin{tabular}{lcc}
\hline Topic and Subtopics & $\mathbf{n}^{\mathbf{a}}$ & $\mathbf{\%}^{\mathbf{a}}$ \\
\hline Fewer cars parked on street & 8 & 0.9 \\
Better general infrastructure & 8 & 0.9 \\
More walking school buses (adult accompanying group of children to school) & 7 & 0.8 \\
Better upkeep of public spaces & 6 & 0.6 \\
Better visibility of the streets & 4 & 0.4 \\
Improved connectivity & 3 & 0.3 \\
Uncodeable & 3 & 0.3 \\
\hline
\end{tabular}

a Data are presented for the number and percentage of parents who noted these topics and subtopics. Note: $n$ and $\%$ of topics do not equate to the total of all the subtopics due to some parents mentioning more than one subtopic in one topic.

\subsection{Quantitative Modelling}

\subsubsection{Descriptive Characteristics}

Sociodemographic characteristics of children were relatively evenly distributed with the exception of ethnicity, where a majority were of New Zealand European/Pākehā/Other European ethnicity (42.3\%) (Table 3). Parental licence for independent mobility scores were positively skewed, ranging from 3.30 to 10.72 with a mean of $5.28(S D=1.67)$. Boys had significantly higher licence for independent mobility than girls $(p<0.001)$. Similarly, older children had significantly higher licence for independent mobility than their younger peers $(p<0.001)$. There was a significant difference in licence for independent mobility between ethnic groups with Pacific children having lower independent mobility than other groups $(p=0.001)$. Almost all parents $(98.4 \%)$ reported having at least one working car available in their household, with $78 \%$ reporting availability of two or more cars. Descriptive information for the objectively assessed neighbourhood environmental features is provided in Table 4.

Table 3. Socio-demographic characteristics of children and their licence for independent mobility $(n=931)$.

\begin{tabular}{|c|c|c|c|c|}
\hline \multirow{2}{*}{ Socio-Demographic Variables } & \multirow{2}{*}{$n$} & \multirow{2}{*}{$\%$} & \multicolumn{2}{|c|}{ Licence for Independent Mobility } \\
\hline & & & Mean (SD) & $p$-Value \\
\hline Sex & & & & $<0.001^{\mathrm{c}}$ \\
\hline Male & 469 & 50.4 & $5.65(1.73)$ & \\
\hline Female & 462 & 49.6 & $5.00(1.67)$ & \\
\hline School level & & & & $<0.001^{\mathrm{c}}$ \\
\hline Primary (years 5-6) & 486 & 52.2 & $4.58(1.32)$ & \\
\hline Intermediate (years 7-8) & 445 & 47.8 & $6.04(1.69)$ & \\
\hline Ethnicity & & & & $0.001^{\mathrm{d}}$ \\
\hline $\begin{array}{l}\text { New Zealand } \\
\text { European/Pākehā/Other European }\end{array}$ & 394 & 42.3 & $5.41(1.61)$ & \\
\hline Māori & 112 & 12.0 & $5.49(1.67)$ & \\
\hline Pacific & 125 & 13.4 & $4.94(1.73)$ & \\
\hline Asian & 120 & 12.9 & $5.04(1.62)$ & \\
\hline MELAA ${ }^{a} /$ Other/Not stated & 180 & 19.3 & $5.25(1.77)$ & \\
\hline Area-level deprivation $b$ & & & & $0.106^{\mathrm{d}}$ \\
\hline Low Deprivation (decile 1-3) & 357 & 38.3 & $5.36(1.67)$ & \\
\hline Medium Deprivation (decile 4-7) & 324 & 34.8 & $5.31(1.65)$ & \\
\hline High Deprivation (decile 8-10) & 250 & 26.9 & $5.13(1.71)$ & \\
\hline
\end{tabular}

${ }^{a}$ MELAA = Middle Eastern, Latin American, or African; ${ }^{b}$ NZDep13 score calculated for each individual household at the meshblock level; ${ }^{c} p$-value from Mann-Whitney U Test; ${ }^{d} p$-value from Kruskal-Wallis H Test. 
Table 4. Descriptive information for objectively-assessed neighbourhood features $(n=931)$.

\begin{tabular}{llll}
\hline Objectively-Assessed Neighbourhood Features $^{\text {a }}$ & Minimum & Maximum & Mean (SD) \\
\hline Ratio of high to low speed roads & 0.00 & 1.00 & $0.37(0.11)$ \\
Number of signalised crossings & 0.00 & 7.00 & $1.01(1.40)$ \\
Ratio of cycle paths to road lengths & 0.00 & 0.74 & $0.12(0.13)$ \\
PedShed b $^{\text {bed }}$ & 0.01 & 0.63 & $0.32(0.11)$ \\
\hline
\end{tabular}

${ }^{a}$ Variable corresponding to parent-reported need; derived within the $800 \mathrm{~m}$ street network individual neighbourhood buffer using Geographic Information Systems; ${ }^{b}$ Ratio of reachable pedestrian network area to the maximum possible area; a higher ratio indicates a more connected pedestrian network.

\subsubsection{Objective 2: Differences in Objectively-Assessed Neighbourhood Features by}

\section{Parent-Reported Needs}

Given the parental focus on transport-related topics (and the availability of corresponding objective data), the following four variables were considered in further analyses related to objective measures and parental licence for independent mobility: less, slower, and safer traffic; more and safer crossings; safer and designated cycle lanes; and more and better walking paths.

Results from mixed effects logistic regression models testing for differences in odds of reporting a need by objectively-assessed neighbourhood built environment and socio-demographic characteristics are presented in Table 5. Taking socio-demographic factors and neighbourhood into account, no statistically significant differences in parent reported needs were observed between those residing in a more or less supportive neighbourhood (objectively assessed). Differences in odds of reporting needs were observed for a range of socio-demographic characteristics. Parents of primary school-aged children had significantly higher odds of reporting a need for less, slower, and safer traffic (OR 1.54, $p=0.014)$, and significantly lower odds of reporting a need for safer and designated cycle lanes (OR $0.48, p=0.003)$. Compared with those of New Zealand/other European ethnicity, parents of children of Pacific ethnicity had significantly lower odds of reporting needing less, slower, and safer traffic; more and safer crossings; and safer and designated cycle lanes (ORs 0.06 to 0.36 , all $p<0.01$ ). All ethnic groups were significantly less likely to report a need for safer and designated cycle lanes compared with the reference group (NZ European/pākehā/other European; ORs 0.06 to 0.51, all $p<0.05$ ). Differences in deprivation were only observed for reporting a need for more and better walking paths, with those from medium or high deprivation areas significantly less likely to report this need compared with those residing in areas of lower deprivation. 
Table 5. Differences in parent-reported needs by objectively-assessed neighbourhood built environment characteristics and socio-demographic factors $(n=931)$.

\begin{tabular}{|c|c|c|c|c|c|c|c|c|}
\hline $\begin{array}{l}\text { Parent-Reported Need }{ }^{\text {a }} \\
n(\%) \text { of Parents Reporting Need }\end{array}$ & \multicolumn{2}{|c|}{$\begin{array}{c}\text { Less, Slower, and Safer Traffic } \\
n=185(19.9 \%)\end{array}$} & \multicolumn{2}{|c|}{$\begin{array}{c}\text { More and Safer Crossings } \\
n=125(13.4 \%)\end{array}$} & \multicolumn{2}{|c|}{$\begin{array}{l}\text { Safer and Designated Cycle Lanes } \\
\qquad n=91(9.8 \%)\end{array}$} & \multicolumn{2}{|c|}{$\begin{array}{c}\text { More and Better Walking Path } \\
n=67(7.2 \%)\end{array}$} \\
\hline \multirow[t]{2}{*}{ Objective Measure } & \multicolumn{2}{|c|}{ Ratio of High to Low Speed Roads } & \multicolumn{2}{|c|}{ Number of Signalised Crossings } & \multicolumn{2}{|c|}{ Ratio of Cycle Path to Road Lengths } & \multicolumn{2}{|c|}{ PedShed $^{b}$} \\
\hline & OR $(95 \% \mathrm{CI})^{\mathrm{c}}$ & $p$-Value & $\mathrm{OR}(95 \% \mathrm{CI})^{\mathrm{c}}$ & $p$-Value & OR $(95 \% \mathrm{CI})^{\mathrm{c}}$ & $p$-Value & OR $(95 \% \mathrm{CI})^{\mathrm{c}}$ & $p$-Value \\
\hline \multicolumn{9}{|l|}{ Objective measure (higher vs. lower) $^{d}$} \\
\hline Lower & Reference & & Reference & & Reference & & Reference & \\
\hline Higher & $0.79(0.54,1.14)$ & 0.208 & $0.90(0.72,1.11)$ & 0.314 & $1.02(0.56,1.87)$ & 0.944 & $0.77(0.34,1.73)$ & 0.527 \\
\hline \multicolumn{9}{|l|}{ Sex } \\
\hline Male & Reference & & Reference & & Reference & & Reference & \\
\hline Female & $0.93(0.67,1.31)$ & 0.693 & $0.73(0.49,1.09)$ & 0.125 & $0.78(0.49,1.24)$ & 0.296 & $0.87(0.47,1.60)$ & 0.527 \\
\hline \multicolumn{9}{|l|}{ School level } \\
\hline Intermediate (years 7-8) & Reference & & Reference & & Reference & & Reference & \\
\hline Primary (years 5-6) & $1.54(1.09,2.19)$ & 0.014 & $1.01(0.67,1.52)$ & 0.980 & $0.48(0.29,0.77)$ & 0.003 & $1.41(0.66,3.00)$ & 0.372 \\
\hline \multicolumn{9}{|l|}{ Ethnicity } \\
\hline NZ European/Pākehā/Other European & Reference & & Reference & & Reference & & Reference & \\
\hline Māori & $0.78(0.43,1.44)$ & 0.432 & $0.60(0.27,1.34)$ & 0.214 & $0.12(0.03,0.52)$ & 0.004 & $0.30(0.06,1.53)$ & 0.147 \\
\hline Pacific & $0.36(0.17,0.76)$ & 0.008 & $0.13(0.03,0.59)$ & 0.008 & $0.06(0.01,0.50)$ & 0.009 & $0.29(0.05,1.55)$ & 0.148 \\
\hline Asian & $0.61(0.34,1.10)$ & 0.103 & $0.48(0.22,1.03)$ & 0.058 & $0.28(0.11,0.75)$ & 0.012 & $0.37(0.07,1.82)$ & 0.220 \\
\hline MELAA a/Other/Not stated & $0.85(0.51,1.42)$ & 0.543 & $0.93(0.49,1.75)$ & 0.816 & $0.51(0.26,1.00)$ & 0.049 & $2.01(0.73,5.52)$ & 0.174 \\
\hline \multicolumn{9}{|l|}{ Area-level deprivation ${ }^{b}$} \\
\hline Low & Reference & & Reference & & Reference & & Reference & \\
\hline Medium & $1.08(0.72,1.61)$ & 0.708 & $0.83(0.53,1.28)$ & 0.396 & $0.84(0.51,1.39)$ & 0.504 & $0.15(0.07,0.33)$ & $<0.001$ \\
\hline High & $1.08(0.60,1.96)$ & 0.796 & $0.50(0.22,1.18)$ & 0.113 & $0.40(0.15,1.08)$ & 0.071 & $0.22(0.07,0.67)$ & 0.008 \\
\hline
\end{tabular}

a Variable corresponding to parent-reported need; derived within the $800 \mathrm{~m}$ street network individual neighbourhood buffer using Geographic Information Systems; ${ }^{\mathrm{b}}$ Measure of walking path availability; area of network buffer/area of radial buffer; ${ }^{\mathrm{c}}$ Estimates from mixed effects logistic regression with random intercept for neighbourhood; ${ }^{\mathrm{d}}$ Objective measures are included in each model as binary variables to compare those with 'higher' and 'lower' objective measures, defined as being above or below the median value for each. 
3.2.3. Objective 3: Relationships between Parental Licence for Independent Mobility and Objective Neighbourhood Features and Parent-Reported Needs

Results from linear mixed models of relationships between objectively-assessed neighbourhood features and parent-reported needs and parental licence for independent mobility are presented in Table 6. No significant interactions between objective neighbourhood environment variables and parent reported needs were observed. In the fully adjusted models, both parent-reported need for safe cycling infrastructure (positive) and objectively-assessed cycle infrastructure (negative) were significantly related to parental licence for independent mobility. Children of parents who thought more dedicated and safer cycle lanes in their neighbourhood would make it better for their children to walk, bike, and scooter, had 0.56 higher parental independent mobility licence score on average, compared to parents who did not mention safer places to cycle $(p=0.001)$. Parent licence for their child's independent mobility was an average of 0.46 lower for those residing in areas with a higher ratio of cycle path to road length compared with those who lived in areas with a lower ratio of cycle path to road length.

Table 6. Mutually adjusted association of parent reported needs and related objective neighbourhood features with children's licence for independent mobility $(n=931)$.

\begin{tabular}{|c|c|c|c|}
\hline $\begin{array}{l}\text { Neighbourhood Variables in } \\
\text { Model }\end{array}$ & Comparison & Estimate $(95 \% \mathrm{CI})^{\text {a }}$ & $p$-Value \\
\hline Ratio of high to low speed roads ${ }^{b}$ & Higher vs. lower & $-0.05(-0.26,0.17)$ & 0.682 \\
\hline Less, slower, and safer traffic ${ }^{c}$ & Parent reported vs. didn't report need & $-0.03(-0.2,0.21)$ & 0.811 \\
\hline Number of signalised crossings ${ }^{b}$ & Per additional crossing & $-0.04(-0.15,0.06)$ & 0.421 \\
\hline More and safer crossings ${ }^{c}$ & Parent reported vs. didn't report need & $0.01(-0.27,0.29)$ & 0.944 \\
\hline Ratio of cycle path to road lengths ${ }^{b}$ & Higher & $-0.46(-0.71,-0.20)$ & 0.001 \\
\hline Safer and designated cycle lanes ${ }^{c}$ & Parent reported vs. didn't report need & $0.56(0.24,0.88)$ & 0.001 \\
\hline PedShed ${ }^{b, d}$ & Ingnes vs. IOWEe & $0.20(-0.01,0.41)$ & 0.058 \\
\hline More and better walking paths ${ }^{c}$ & Parent reported vs. didn't report need & $-0.14(-0.55,0.27)$ & 0.506 \\
\hline
\end{tabular}

${ }^{a}$ Linear mixed models with random intercept for neighbourhood to account for neighbourhood clustering, including the objectively-assessed neighbourhood feature and the related parent-reported need, and adjusted for sex of child, school year level, ethnicity, and meshblock-level deprivation; ${ }^{\mathrm{b}}$ Objectively assessed variable corresponding to parent-reported need; derived within the $800 \mathrm{~m}$ street network individual neighbourhood buffer using Geographic Information Systems; ${ }^{c}$ Parent-reported need; ${ }^{d}$ Measure of walking path availability; area of network buffer/area of radial buffer.

\section{Discussion}

The aim of this study was to understand factors related to parental licence for their child's independent mobility in a large sample of parents of children aged 8-13 years residing in Auckland, New Zealand. A sequential approach was taken using mixed methods. Firstly, data derived from parent interviews were used to determine factors that parents perceived would make their neighbourhood better for their child to be independently mobile. Secondly, objective neighbourhood built environment variables were generated and examined in relation to parent reported needs. Finally, associations between parental licence for their child's independent mobility were determined with key objective and perceived neighbourhood variables. Key findings were that: (1) parents identified a need for safer traffic environments for their child's independent mobility; (2) no significant differences were observed between objective neighbourhood built environment measures and parents' reported neighbourhood needs; and (3) parental licence for their child's independent mobility was positively associated with parent perceptions that dedicated and safer places to bike were needed in their neighbourhood and negatively associated with residing in an area with a higher ratio of cycle path to road lengths. These findings are discussed in detail below and contextualized within independent mobility literature, supplemented by evidence for children's active travel where relevant. 


\subsection{Objective 1: Parents' Perceptions on What Would Make Their Neighbourhood Better for Independent Mobility}

Content analysis of parents' answers to the question "what would make their neighbourhoods better for their child to walk, cycle and scooter in?" showed that a majority of the parents believed aspects of their neighbourhood could be improved. A key finding was that parents identified a safer traffic environment as a major need for their children's independent mobility ( $50.3 \%$ of parents overall). Particularly, less, slower, and safer traffic (19.9\%); more pedestrian crossings (13.4\%); more designated cycle lanes $(9.8 \%)$; and more and better walking paths $(7.2 \%)$ were considered important aspects.

Traffic safety is consistently a parental concern and limiting factor for children's independent mobility $[35,67,68]$ and active travel in general. The current study findings aligned closely with the body of work in this field, for example in the early focus group research of Ahlport and colleagues [69], parents identified high traffic volume, dangerous drivers, and busy intersections as specific barriers to their child's active travel.

For the most part, findings related to perceptions of transport infrastructure also aligned with previous research. For example, parental concern for lack of pedestrian crossings was related to less active travel in a study of Australian children [29] and presence of pedestrian crossings was associated with more independent travel in a later study [49]. On the contrary, Evers and colleagues [70] found that traffic lights, marked crossings, and bump-out crossings did not influence parents' concern for their children crossing the road. However, these results were based on whether the parent would let an eight-year-old child cross the road unsupervised, and the age of the child may have been a bigger influence on parental concerns than the crossing infrastructure. In the current study, almost $5 \%$ of parents noted that age of their child was the key driver of their child's independent mobility licence, rather than the neighbourhood environment. There is likely an age and stage threshold below which infrastructure and neighbourhood perceptions are irrelevant in determining whether a child is allowed to be independently mobile.

Parents also highlighted the need for safe places to walk and cycle as key environmental considerations. These findings add to a small evidence base about the importance of availability and condition (e.g., uneven surfaces, obstacles, overgrown vegetation) of walking paths for children's independent mobility [70]. As well as providing a safe place to walk, the availability of walking paths may be important as this can reduce the need to cross roads to reach a destination [69]. In an adult sample, half of the respondents believed that lack of sidewalks in their neighbourhood was a problem and was a barrier to them being physically active [71]. Parents also noted the condition of walking paths, specifically that paths should be well maintained and wide enough for children to safely walk and cycle away from the road.

Safe places to cycle were also identified by parents as key infrastructural features that would create a supportive environment for children to be independently mobile. Specifically, parents mentioned the need for cycle lanes that are dedicated and separated from the road. This preference aligns with earlier research reporting on parental views on the importance of cycling infrastructure [28,72]. More specifically, cycle lanes that are separated from road traffic are perceived vital to cycling safety by parents. When considering relative importance of varying traffic infrastructure, one study reported that parents' perceived physical separation of child cyclists and the road was more important than a lower speed limit [73].

Safety from others was also raised by $12 \%$ of parents, with a focus on concerns about "stranger danger" (5.4\% of parents) and a need for greater community surveillance $(4.6 \%)$. To a lesser extent, criminal and gang activity, roaming dogs, other "undesirables", and bullying were also identified as factors limiting children's independent mobility. Concern about safety from strangers is an established barrier to parents granting licence for independent mobility to their child $[9,34,46]$ as is the fear of crime [32]. Increased perceived social cohesion is associated with greater independent licence as it may support the perception of a safer neighbourhood for children [31]. However, Foster and colleagues [34] found no association between informal social control and decreased fear of strangers, indicating 
that the these perceptions are multifaced and may not be alleviated simply by a more supportive neighbourhood community.

\subsection{Objective 2: Perceived and Objective Aspects of the Neighbourhood Transport Environment}

In fully adjusted models, no statistically significant differences were observed in parent reported needs by different levels of the objective measures. In other words, no significant association was found between the objectively-assessed neighbourhood features and reporting a need. This finding was somewhat expected, considering that while the perceived and objective measures were theorized to relate to each other, they were not assessing the same environmental dimensions exactly (as detailed in Table 1). Additionally, a growing body of evidence has shown that adult perceptions do not always align with objective measures of the neighbourhood environment $[71,74,75]$. Rothman and colleagues [76] concluded that there are some differences between parents' perception and objective measures of traffic safety along school routes. However, some specific measures such as road crossings were related to lower parental perceived traffic danger. McGinn and colleagues [71] also found no agreement between perceived fast and heavy traffic and objectively measured speed and traffic volume. It is likely that both approaches provide valuable insights, and the triangulation of multiple data sources is optimal to gain a comprehensive understanding of environmental features of importance. Indeed, past research examining objective and perceived measures of the neighbourhood environment in relation to independent mobility has shown mixed results. Marzi and colleagues [41] concluded from their systematic review that parental perceptions of traffic have a greater influence in determining children's independent mobility compared with objective measures of the physical environment. Looking across the lifespan, perceptions were stronger indicators than objective measures for physical activity in preschoolers [77], active travel to school in children [78], and adults walking in their neighbourhood [79]. On the contrary, there is evidence that adults' physical activity is supported by urban design features regardless of their perception of the neighbourhood [80]. In adult populations, both McGinn and colleagues [71] and Lee and Dean [81] concluded that it may be necessary that both perceptions and objective measures of the neighbourhood environment are used to understand the complexity of the relationship between the built environment, walkability, and physical activity.

After adjusting for all other factors, differences in parents' perceived needs by socio-demographic characteristics were observed, including child's school level (less, slower, and safer traffic; cycling infrastructure), ethnicity (all variables except walking infrastructure), and area level deprivation (walking infrastructure only). These novel findings highlight the link between socio-demographic factors and neighbourhood perceptions as well as aiding understanding relationships between perceived and objective environments. Parents of younger children had 1.5 times the odds of reporting a need for less, slower, and safer traffic compared with those of older children. This implies the age of a child influences parent traffic safety perceptions, more so than the actual traffic environment. Compared with older children, a higher traffic safety threshold may be required for younger children in order for parents to perceive their environment as being safe. Conversely, parents of younger children were half as likely to report a need for safer and designated cycling infrastructure. It is possible this is due to lower levels of cycling in younger children compared with older children in this study (data not reported here) and thus cycling infrastructure being less relevant for these parents. In a similar manner, all ethnic groups were significantly less likely to report a need for safer and designated cycle lanes compared with parents of children who identified as being of New Zealand European/Pākehā/Other European ethnicity. National travel survey data suggest significantly higher rates in those of New Zealand European ethnicity compared with other ethnic groups (and low rates of cycling overall) [82]. Parents of children of Pacific ethnicity also had significantly lower odds of reporting needing less, slower, and safer traffic; more and safer crossings. It is unclear why these differences existed-further work examining ethnic differences in neighbourhood perceptions would be worthwhile.

Differences in deprivation were only observed for reporting a need for more and better walking paths, with those from higher deprivation areas significantly less likely to report this need compared 
with those residing in higher deprivation. It is possible this is a reflection of the New Zealand context, where positive relationships have been found consistently between walkability elements (e.g., destination accessibility) and deprivation [83].

\subsection{Objective 3: Factors Associated with Parent Licence for Independent Mobility}

Independent mobility licence was significantly related to both parent-reported need for safer cycling infrastructure and objectively-assessed cycle infrastructure. Children had a higher independent mobility licence when their parents mentioned that their neighbourhood needed more dedicated and safer cycle lanes, compared with children of parents who did not mention cycling infrastructure. This finding aligns with earlier work by Timperio and colleagues [29] indicating it is possible that parents are more aware of their traffic environment when they grant their children more independent mobility licence. Specifically, if children cycle in their neighbourhood, parents may notice the lack of cycle lanes available for their children, while in comparison parents who grant low mobility licence may not identify the need for more cycling lanes. Neighbourhood self-selection [39] may play a role in understanding parent perceptions. It is possible that parents who prefer neighbourhoods with safer transport infrastructure have chosen to live in neighbourhoods that align with this preference, yet their own personal preferences are still not being met sufficiently.

In terms of objectively measured cycling infrastructure, children with higher parental licence for independent mobility lived in areas with lower cycle lane availability. This finding could be due to parents allowing their children to be independently mobile, but more so for walking rather than cycling. Indeed, Moran and colleagues [53] concluded that walking is a more common form of independent mobility than cycling, and that different built environmental features are associated with each type of active travel mode.

No other significant associations with independent mobility were found. Inconsistent findings have been observed in earlier literature with regard to links between parental perceptions and children's independent mobility. Traffic safety perceptions of parents was positively associated with adolescent active travel [84] and independent mobility in girls [72]. Conversely, Santos and colleagues [43] found no association with traffic safety and independent mobility. Perceived poor availability of road crossings has been associated with decreased independent mobility for boys [51] and decreased active travel in children, generally $[85,86]$. In other studies, parent perceptions of available walking paths was a predictor for independent mobility [43] and active travel [28].

A recent meta-analysis identified a number of built environment features related to children's independent mobility (operationalized as independent mobility time, independent mobility to destinations, territorial range, or licence for independent mobility) [52]. Positive associations were found for proportion of residential land, proportion of commercial land, residential location type, and dead-end streets. Negative associations were observed for vehicular street width, road density, street connectivity, proportion of major roads, land use mix, availability of recreational facilities, residential density, and distance to destinations. Situating the current study findings with the extant literature, it is clear that understanding determinants of children's independent mobility is a complex challenge. Factors exist across the socio-ecological spectrum [23], and the role of parenting practices, beliefs, and perceptions in this context cannot be underestimated [87]. Nuances may also exist, whereby differences in relationships might be expected by neighbourhood social and built environment contexts and spatio-temporal factors may also play a role. For example, earlier work with Auckland children showed that active travel was associated with destination accessibility on weekdays only, and differential relationships between activity and built environment characteristics were also observed between weekend days and weekdays [54].

\section{Strengths and Limitations}

This study was cross-sectional and conducted in one city in New Zealand only. Findings cannot be generalized to other environments, and causality cannot be inferred. Parental licence for their child's 
independent mobility was employed in the current study to align with the majority of literature in this field. However, it is important to recognise this measure does not necessarily encompass all facets of children's independent mobility (e.g., time, range, destinations) and that children may also report their independence differently from their parents. Had different measures of independent mobility been used in the current study, it is possible alternative findings might have been identified. It is also worth noting that broader family and household characteristics may play an important role in children's independent mobility, including having older siblings, household car ownership, competing family schedules, and neighbourhood self-selection. The latter three variables were not measured in this examination. The almost universal access to a working car in this study hindered any ability to detect the effect of not having access to a car on children's independent mobility. The pervasiveness of the car is consistent with national data. New Zealand has one of the highest rates of car ownership internationally and rates have continued to rise in recent years [88]. It is possible these broader factors are more likely to be linked to children's actualized independent mobility, rather than parental licence for independent mobility, and further work in this area is needed. It is also possible that other parent psychological factors and experiences may have contributed to understanding children's independent mobility and parent neighbourhood perceptions, however these were not examined in the current investigation. For example, factors such as anxiety, values around child independence, incidences or 'near misses', and local narratives about past incidents related to child independent mobility could all play a role in how a parent perceives their environment and thus impact the independence granted to their child.

No agreed upon approach for determining neighbourhood buffers for children's independent mobility exists. Previous examinations in Neighbourhoods for Active Kids have used a range of study-specific buffers to determine environments of importance including $800 \mathrm{~m}$ around schools only for outdoor advertising [63], $800 \mathrm{~m}$ around home plus school (less any overlap) for children's body size [65], and school route only using $80 \mathrm{~m}$ on each side of the street centre line for active school travel [64]. The "home only" buffer was determined for the current study to align with the study's focus on parent perceptions about their neighbourhood and their child's independence in the neighbourhood. Not all children lived within close proximity to school, so including a school buffer to characterize the objective built environment and examine this in relation to parent perceptions would have reduced sensitivity and specificity. Previous research with Auckland children supported a $1000 \mathrm{~m}$ buffer to capture levels of MVPA [54]. Conversely, a Canadian study showed $500 \mathrm{~m}$ was optimal to measure associations with girls' MVPA, and $800 \mathrm{~m}$ was best for boys' MVPA [89]. An $800 \mathrm{~m}$ buffer was chosen in the current study as a pragmatic approach to capture sufficient environmental features that might be 'front of mind' for parents when considering their neighbourhood and their child's independent mobility, and to allow comparability with previous research $[51,54,89]$. Future research would benefit from the use of more individually-centred measures such as activity spaces [90].

\section{Conclusions}

Through the use of mixed methods with a large sample of parents, this study provides a comprehensive examination of children's independent mobility licence, parent neighbourhood perceptions, and objectively assessed neighbourhood built environments. For the first time, objective pedestrian crossing and cycle lane availability has been examined in relation to children's independent mobility, contributing to improving sensitivity and specificity in neighbourhood built environment measures. Novel findings on relationships between socio-demographic characteristics and parent neighbourhood perceptions can help interpret research exploring differences between perceived and objectively-assessed neighbourhood features. Further research is needed to explore the complex relationships between parent psychological characteristics, family and household context, perceived and objective neighbourhood environments and children's actualized independent mobility and licence for independent mobility across a range of settings. Novel findings demonstrate the importance of measuring both perceived and objective characteristics, and exploring why these do not always 
align. Overall, this novel study demonstrates the importance of providing safer traffic environments, particularly safer places to cycle, for children's independent mobility.

Author Contributions: M.S., K.W., S.M., R.K., R.M. and P.C. conceptualised and developed the Neighbourhoods for Active Kids study, and secured funding for the study. M.S., K.W., P.C., L.M. and E.I. were involved in participant recruitment and data collection. M.S. and D.R. led the qualitative data coding and framework development. R.A. and A.C. led the quantitative data modelling and interpretation. S.M., J.Z. and E.F. led the development of objective neighbourhood built environment factors. M.S. and R.A. prepared the full draft manuscript. All authors contributed to interpretation of research findings. All authors read, contributed edits to, and approved the final manuscript.

Funding: Neighbourhoods for Active Kids was supported by the Health Research Council of New Zealand (grant number 14/436). R.A. was supported by a University of Auckland Faculty of Medical and Health Sciences summer research scholarship. M.S. is supported by a Health Research Council of New Zealand Sir Charles Hercus Research Fellowship (grant number 17/013). S.M. is supported by an Australian National Health and Medical Research Council Early Career Fellowship (grant number 1121035).

Acknowledgments: The authors would like to acknowledge the support and time of children who participated in the Neighbourhoods for Active Kids Study, their parents and caregivers, and schools.

Conflicts of Interest: The authors declare no conflict of interest.

\section{References}

1. Strong, W.B.; Malina, R.M.; Blimkie, C.J.; Daniels, S.R.; Dishman, R.K.; Gutin, B.; Hergenroeder, A.C.; Must, A.; Nixon, P.A.; Pivarnik, J.M.; et al. Evidence based physical activity for school-age youth. J. Pediatr. 2005, 146, 732-737. [CrossRef]

2. Aubert, S.; Barnes, J.D.; Abdeta, C.; Abi Nader, P.; Adeniyi, A.F.; Aguilar-Farias, N.; Andrade Tenesaca, D.S.; Bhawra, J.; Brazo-Sayavera, J.; Cardon, G.; et al. Global Matrix 3.0 Physical Activity Report Card Grades for Children and Youth: Results and Analysis from 49 Countries. J. Phys. Act. Health 2018, 15, S251-S273. [CrossRef]

3. Smith, M.; Ikeda, E.; Hinckson, E.; Duncan, S.; Maddison, R.; Meredith-Jones, K.; Walker, C.; Mandic, S. Results from New Zealand's 2018 Report card on Physical Activity for Children and Youth. J. Phys. Act. Health 2018, 15, S390-S392. [CrossRef]

4. Hillman, M.; Adams, J.; Whitelegg, J. One False Move ... A Study of Children's Independent Mobility; Policy Studies Institute: London, UK, 1990; ISBN 0853744947.

5. Chaudhury, M.; Oliver, M.; Badland, H.M.; Mavoa, S. Public Open Spaces, Children's Independent Mobility. In Play, Recreation, Health and Well Being, Geographies of Children and Young People; Evans, B., Horton, J., Eds.; Springer Science: Singapore, 2015; Volume 9, pp. 315-335.

6. Marzi, I.; Reimers, A.K. Children's Independent Mobility: Current Knowledge, Future Directions, and Public Health Implications. Int. J. Environ. Res. Public Health 2018, 15, 2441. [CrossRef]

7. Riazi, N.A.; Faulkner, G. Children's Independent Mobility. In Children's Active Transportation, 1st ed.; Larouche, R., Ed.; Elsevier: Amsterdam, The Netherlands, 2018; pp. 77-87.

8. Ikeda, E.; Hinckson, E.; Witten, K.; Smith, M. Assessment of direct and indirect associations between children active school travel and environmental, household and child factors using structural equation modelling. Int. J. Behav. Nutr. Phys. Act. 2019, 16, 32. [CrossRef]

9. Mitra, R.; Faulkner, G.E.; Buliung, R.N.; Stone, M.R. Do parental perceptions of the neighbourhood environment influence children's independent mobility? Evidence from Toronto, Canada. Urban Stud. 2014, 51, 3401-3419. [CrossRef]

10. Oliver, M.; Parker, K.; Witten, K.; Mavoa, S.; Badland, H.M.; Donovan, P.; Chaudhury, M.; Kearns, R. Children's Out-of-School Independently Mobile Trips, Active Travel, and Physical Activity: A Cross-Sectional Examination from the Kids in the City Study. J. Phys. Act. Health 2016, 13, 318-324. [CrossRef]

11. Schoeppe, S.; Duncan, M.J.; Badland, H.; Oliver, M.; Curtis, C. Associations of children's independent mobility and active travel with physical activity, sedentary behaviour and weight status: A systematic review. J. Sci. Med. Sport 2013, 16, 312-319. [CrossRef]

12. Stone, M.R.; Faulkner, G.E.; Mitra, R.; Buliung, R.N. The freedom to explore: Examining the influence of independent mobility on weekday, weekend and after-school physical activity behaviour in children living in urban and inner-suburban neighbourhoods of varying socioeconomic status. Int. J. Behav. Nutr. Phys. Act. 2014, 11, 5. [CrossRef] 
13. Bento, G.; Dias, G. The importance of outdoor play for young children's healthy development. Porto Biomed. J. 2017, 2, 157-160. [CrossRef]

14. Pooley, C.; Whyatt, D.; Walker, M.; Davies, G.; Coulton, P.; Bamford, W. Understanding the school journey: Integrating data on travel and environment. Environ. Plan. A 2010, 42, 948-965. [CrossRef]

15. Prezza, M.; Pilloni, S.; Morabito, C.; Sersante, C.; Alparone, F.R.; Giuliani, M.V. The influence of psychosocial and environmental factors on children's independent mobility and relationship to peer frequentation. J. Community Appl. Soc. Psychol. 2001, 11, 435-450. [CrossRef]

16. Prezza, M.; Pacilli, M.G. Current fear of crime, sense of community, and loneliness in italian adolescents: The role of autonomous mobility and play during childhood. J. Community Psychol. 2007, 35, 151-170. [CrossRef]

17. Rissotto, A.; Tonucci, F. Freedom of Movement and Environmental Knowledge in Elementary School Children. J. Environ. Psychol. 2002, 22, 65-77. [CrossRef]

18. Mitchell, H.; Kearns, R.; Collins, D.C.A. Nuances of neighbourhood: Children's perceptions of the space between home and school in Auckland, New Zealand. Geoforum 2007, 38, 614-627. [CrossRef]

19. Mackett, R.; Brown, B.; Gong, Y.; Kitazawa, K.; Paskins, J. Children's Independent Movement in the Local Environment. Built Environ. 2007, 33, 454-468. [CrossRef]

20. Schoeppe, S.; Tranter, P.; Duncan, M.J.; Curtis, C.; Carver, A.; Malone, K. Australian children's independent mobility levels: Secondary analyses of cross-sectional data between 1991 and 2012. Child.'s Geogr. 2016, 14, 408-421. [CrossRef]

21. Shaw, B.; Bicket, M.; Elliott, B.; Fagan-Watson, B.; Mocca, E.; Hillman, M. Children's Independent Mobility: An International Comparison and Recommendations for Action; Policy Studies Institute: London, UK, 2015; ISBN 9780853740148.

22. Sallis, J.F.; Cervero, R.B.; Ascher, W.; Henderson, K.A.; Kraft, M.K.; Kerr, J. An ecological approach to creating active living communities. Annu. Rev. Public Health 2006, 27, 297-322. [CrossRef]

23. Badland, H.; Kearns, R.; Carroll, P.; Oliver, M.; Mavoa, S.; Donovan, P.; Parker, K.; Chaudhury, M.; Lin, E.Y.; Witten, K. Development of a systems model to visualise the complexity of children's independent mobility. Child.'s Geogr. 2016, 14, 91-100. [CrossRef]

24. Cordovil, R.; Lopes, F.; Neto, C. Children's (in)dependent mobility in Portugal. J. Sci. Med. Sport 2015, 18, 299-303. [CrossRef]

25. Egli, V.; Ikeda, E.; Stewart, T.; Smith, M. Interpersonal Correlates of Active Transportation. In Children's Active Transportation, 1st ed.; Larouche, R., Ed.; Elsevier: Amsterdam, The Netherlands, 2018; pp. 115-125.

26. Crawford, S.B.; Bennetts, S.K.; Hackworth, N.J.; Green, J.; Graesser, H.; Cooklin, A.R.; Matthews, J.; Strazdins, L.; Zubrick, S.R.; D’Esposito, F.; et al. Worries, 'weirdos', neighborhoods and knowing people: A qualitative study with children and parents regarding children's independent mobility. Health Place 2017, 45, 131-139. [CrossRef]

27. Carver, A.; Timperio, A.; Crawford, D. Playing it safe: The influence of neighbourhood safety on children's physical activity-A review. Health Place 2008, 14, 217-227. [CrossRef]

28. De Meester, F.; Van Dyck, D.; De Bourdeaudhuij, I.; Cardon, G. Parental perceived neighborhood attributes: Associations with active transport and physical activity among 10-12 year old children and the mediating role of independent mobility. BMC Public Health 2014, 14, 631. [CrossRef]

29. Timperio, A.; Crawford, D.; Telford, A.; Salmon, J. Perceptions about the local neighborhood and walking and cycling among children. Prev. Med. 2004, 38, 39-47. [CrossRef]

30. Janssen, I.; Ferrao, T.; King, N. Individual, family, and neighborhood correlates of independent mobility among 7 to 11-year-olds. Prev. Med. Rep. 2016, 3, 98-102. [CrossRef]

31. Schoeppe, S.; Duncan, M.J.; Badland, H.M.; Alley, S.; Williams, S.; Rebar, A.L.; Vandelanotte, C. Socio-demographic factors and neighbourhood social cohesion influence adults' willingness to grant children greater independent mobility: A cross-sectional study. BMC Public Health 2015, 15, 690. [CrossRef]

32. Wolfe, M.K.; McDonald, N.C. Association between neighborhood social environment and children's independent mobility. J. Phys. Act. Health 2016, 13, 970-979. [CrossRef]

33. Carver, A.; Panter, J.R.; Jones, A.P.; van Sluijs, E.M.F. Independent mobility on the journey to school: A joint cross-sectional and prospective exploration of social and physical environmental influences. J. Transp. Health 2014, 1, 25-32. [CrossRef] 
34. Foster, S.; Villanueva, K.; Wood, L.; Christian, H.; Giles-Corti, B. The impact of parents' fear of strangers and perceptions of informal social control on children's independent mobility. Health Place 2014, 26, 60-68. [CrossRef]

35. Lopes, F.; Cordovil, R.; Neto, C. Children's independent mobility in Portugal: Effects of urbanization degree and motorized modes of travel. J. Transp. Geogr. 2014, 41, 210-219. [CrossRef]

36. Lin, E.Y.; Witten, K.; Smith, M.; Carroll, P.; Asiasiga, L.; Badland, H.; Parker, K. Social and built-environment factors related to children's independent mobility: The importance of neighbourhood cohesion and connectedness. Health Place 2017, 46, 107-113. [CrossRef]

37. Carver, A.; Barr, A.; Singh, A.; Badland, H.; Mavoa, S.; Bentley, B. How are the built environment and household travel characteristics associated with children's active transport in Melbourne, Australia? J. Transp. Health 2019, 12, 115-129. [CrossRef]

38. Heinen, E.; van Wee, B.; Panter, J.; Mackett, R.; Ogilvie, D. Residential self-selection in quasi-experimental and natural experimental studies: An extended conceptualization of the relationship between the built environment and travel behavior. J. Transp. Land Use 2018, 11, 939-959. [CrossRef]

39. Levine, J.; Inam, A.; Torng, G.-W. A Choice-Based Rationale for Land Use and Transportation Alternatives. J. Plan. Educ. Res. 2005, 24, 317-330. [CrossRef]

40. Oliver, M.; Badland, H.; Mavoa, S.; Witten, K.; Kearns, R.; Ellaway, A.; Hinckson, E.; Mackay, L.; Schluter, P.J. Environmental and socio-demographic associates of children's active transport to school: A cross-sectional investigation from the URBAN Study. Int. J. Behav. Nutr. Phys. Act. 2014, 11, 70. [CrossRef]

41. Marzi, I.; Demetriou, Y.; Reimers, A.K. Social and physical environmental correlates of independent mobility in children: A systematic review taking sex/gender differences into account. Int. J. Health Geogr. 2018, 17, 24. [CrossRef]

42. Nicksic, N.E.; Salahuddin, M.; Butte, N.F.; Hoelscher, D.M. Associations Between Parent-Perceived Neighborhood Safety and Encouragement and Child Outdoor Physical Activity Among Low-Income Children. J. Phys. Act. Health 2018, 15, 317-324. [CrossRef]

43. Santos, M.P.; Pizarro, A.N.; Mota, J.; Marques, E.A. Parental physical activity, safety perceptions and children's independent mobility. BMC Public Health 2013, 12, 584. [CrossRef]

44. Giles-Corti, B.; Kelty, S.F.; Zubrick, S.R.; Villanueva, K.P. Encouraging walking for transport and physical activity in children and adolescents: How important is the built environment? Sports Med. 2009, 39, 995-1009. [CrossRef]

45. Christian, H.E.; Klinker, C.D.; Villanueva, K.; Knuiman, M.W.; Foster, S.A.; Zubrick, S.R.; Divitini, M.; Wood, L.; Giles-Corti, B. The effect of the social and physical environment on children's independent mobility to neighborhood destinations. J. Phys. Act. Health 2015, 12, S84-S93. [CrossRef]

46. Francis, J.; Martin, K.; Wood, L.; Foster, S. 'I'll be driving you to school for the rest of your life': A qualitative study of parents' fear of stranger danger. J. Environ. Psychol. 2017, 53, 112-120. [CrossRef]

47. Ikeda, E.; Hinckson, E.; Witten, K.; Smith, M. Associations of children's active school travel with perceptions of the physical environment and characteristics of the social environment: A systematic review. Health Place 2018, 54, 118-131. [CrossRef]

48. Carroll, P.; Witten, K.; Kearns, R.; Donovan, P. Kids in the City: Children's use and experiences of urban neighbourhoods in Auckland, New Zealand. J. Urban Des. 2015, 20, 417-436. [CrossRef]

49. Johansson, M. Environment and parental factors as determinants of mode for children's leisure travel. J. Environ. Psychol. 2006, 26, 156-169. [CrossRef]

50. Kyttä, M. The extent of children's independent mobility and the number of actualized affordances as criteria for child-friendly environments. J. Environ. Psychol. 2004, 24, 179-198. [CrossRef]

51. Villanueva, K.; Giles-Corti, B.; Bulsara, M.; Timperio, A.; McCormack, G.; Beesley, B.; Trapp, G.; Middleton, N. Where Do Children Travel to and What Local Opportunities Are Available? The Relationship Between Neighborhood Destinations and Children's Independent Mobility. Environ. Behav. 2012, 45, 679-705. [CrossRef]

52. Sharmin, S.; Kamruzzaman, M. Association between the built environment and children's independent mobility: A meta-analytic review. J. Transp. Geogr. 2017, 61, 104-117. [CrossRef]

53. Moran, M.R.; Plaut, P.; Baron-Epel, O. Do children walk where they bike? Exploring built environment correlates of children's walking and bicycling. J. Transp. Land Use 2015, 9, 43-65. [CrossRef] 
54. Oliver, M.; Mavoa, S.; Badland, H.; Parker, K.; Donovan, P.; Kearns, R.A.; Lin, E.Y.; Witten, K. Associations between the neighbourhood built environment and out of school physical activity and active travel: An examination from the Kids in the City study. Health Place 2015, 36, 57-64. [CrossRef]

55. Villanueva, K.; Giles-Corti, B.; Bulsara, M.; Trapp, G.; Timperio, A.; McCormack, G.; Van Niel, K. Does the walkability of neighbourhoods affect children's independent mobility, independent of parental, socio-cultural and individual factors? Child.'s Geogr. 2014, 12, 393-411. [CrossRef]

56. Giles-Corti, B.; Wood, G.; Pikora, T.; Learnihan, V.; Bulsara, M.; Van Niel, K.; Timperio, A.; McCormack, G.; Villanueva, K. School site and the potential to walk to school: The impact of street connectivity and traffic exposure in school neighborhoods. Health Place 2011, 17, 545-550. [CrossRef]

57. Badland, H.; Donovan, P.; Mavoa, S.; Oliver, M.; Chaudhury, M.; Witten, K. Assessing neighbourhood destination access for children: Development of the NDAI-C audit tool. Environ. Plan. B Plan. Des. 2015, 42, 1148-1160. [CrossRef]

58. Uys, M.; Broyles, S.T.; Draper, C.E.; Hendricks, S.; Rae, D.; Naidoo, N.; Katzmarzyk, P.T.; Lambert, E.V. Perceived and objective neighborhood support for outside of school physical activity in South African children. BMC Public Health 2016, 16, 462. [CrossRef]

59. Statistics New Zealand. 2013 Census QuickStats About a Place: Auckland Region. Available online: http://archive.stats.govt.nz/Census/2013-census/profile-and-summary-reports/quickstats-about-aplace.aspx?request_value=13170\&tabname $=($ accessed on 10 April 2019).

60. Witten, K.; Kearns, R.; Carroll, P.; Asiasiga, L. Children's everyday encounters and affective relations with place: Experiences of hyperdiversity in Auckland neighbourhoods. Soc. Cult. Geogr. 2017, 9365, 1-18. [CrossRef]

61. Oliver, M.; McPhee, J.; Carroll, P.; Ikeda, E.; Mavoa, S.; Mackay, L.; Kearns, R.A.; Kyttä, M.; Asiasiga, L.; Garrett, N.; et al. Neighbourhoods for Active Kids: Study protocol for a cross-sectional examination of neighbourhood features and children's physical activity, active travel, independent mobility and body size. BMJ Open 2016, 6, e013377. [CrossRef]

62. Ministry of Education. School Deciles. Available online: https://www.education.govt.nz/school/running-aschool/resourcing/operational-funding/school-decile-ratings/ (accessed on 10 April 2019).

63. Egli, V.; Zinn, C.; Mackay, L.; Donnellan, N.; Villanueva, K.; Mavoa, S.; Exeter, D.J.; Vandevijvere, S.; Smith, M. Viewing obesogenic advertising in children's neighbourhoods using Google Street View. Geogr. Res. 2018, 57, 84-97. [CrossRef]

64. Ikeda, E.; Mavoa, S.; Hinckson, E.; Witten, K.; Donnellan, N.; Smith, M. Differences in child-drawn and GIS-modelled routes to school: Impact on space and exposure to the built environment in Auckland, New Zealand. J. Transp. Geogr. 2018, 71, 103-115. [CrossRef]

65. Egli, V. Neighbourhoods for Healthy Kids: A Child-Centred Investigation into the Role of the Built Environment on Child Body Size; Auckland University of Technology: Auckland, New Zealand, 2019.

66. Atkinson, J.; Salmond, C.; Crampton, P. NZDep2013 Index of Deprivation; Department of Public Health, University of Otago: Wellington, New Zealand, 2014.

67. Fyhri, A.; Hjorthol, R.; Mackett, R.; Fotel, T.N.; Kyttä, M. Children's active travel and independent mobility in four countries: Development, social contributing trends and measures. Transp. Policy 2011, 8, 703-710. [CrossRef]

68. Jago, R.; Thompson, J.L.; Page, A.S.; Brockman, R.; Cartwright, K.; Fox, K.R. Licence to be active: Parental concerns and 10-11-year-old children's ability to be independently physically active. J. Public Health 2009, 31, 472-477. [CrossRef] [PubMed]

69. Ahlport, K.N.; Linnan, L.; Vaughn, A.; Evenson, K.R.; Ward, D.S.; Carmen Head, B.J. Barriers to and Facilitators of Walking and Bicycling to School: Formative Results From the Non-Motorized Travel Study. Health Educ. Behav. 2008, 35, 221-244. [CrossRef]

70. Evers, C.; Boles, S.; Johnson-Shelton, D.; Schlossberg, M.; Richey, D. Parent Safety Perceptions of Child Walking Routes. J. Transp. Health 2014, 1, 108-115. [CrossRef] [PubMed]

71. McGinn, A.P.; Evenson, K.R.; Herring, A.H.; Huston, S.L.; Rodriguez, D.A. Exploring Associations between Physical Activity and Perceived and Objective Measures of the Built Environment. J. Urban Health 2007, 84, 162-184. [CrossRef]

72. Ghekiere, A.; Deforche, B.; Carver, A.; Mertens, L.; de Geus, B.; Clarys, P.; Cardon, G.; De Bourdeaudhuij, I.; Van Cauwenberg, J. Insights into children's independent mobility for transportation cycling-Which socio-ecological factors matter? J. Sci. Med. Sport 2017, 20, 267-272. [CrossRef] 
73. Nevelsteen, K.; Steenberghen, T.; Van Rompaey, A.; Uyttersprot, L. Controlling factors of the parental safety perception on children's travel mode choice. Accid. Anal. Prev. 2012, 45, 39-49. [CrossRef] [PubMed]

74. Lee, S.M.; Conway, T.L.; Frank, L.D.; Saelens, B.E.; Cain, K.L.; Sallis, J.F. The Relation of Perceived and Objective Environment Attributes to Neighborhood Satisfaction. Environ. Behav. 2017, 49, 136-160. [CrossRef]

75. Schüle, S.; Nanninga, S.; Dreger, S.; Bolte, G.; Schüle, S.A.; Nanninga, S.; Dreger, S.; Bolte, G. Relations between Objective and Perceived Built Environments and the Modifying Role of Individual Socioeconomic Position. A Cross-Sectional Study on Traffic Noise and Urban Green Space in a Large German City. Int. J. Environ. Res. Public Health 2018, 15, 1562. [CrossRef] [PubMed]

76. Rothman, L.; Buliung, R.; To, T.; Macarthur, C.; Macpherson, A.; Howard, A. Associations between parents perception of traffic danger, the built environment and walking to school. J. Transp. Health 2015, 2, 327-335. [CrossRef]

77. Eichinger, M.; Schneider, S.; De Bock, F. Subjectively and objectively assessed social and physical environmental correlates of preschoolers' accelerometer-based physical activity. Int. J. Behav. Nutr. Phys. Act. 2017, 14, 1-13. [CrossRef]

78. Kerr, J.; Rosenberg, D.; Sallis, J.F.; Saelens, B.E.; Frank, L.D.; Conway, T.L.; Rosenberg, D.; Sallis, J.F.; Saelens, B.E.; Frank, L.D.; et al. Active Commuting to School: Associations with Environment and Parental Concerns. Am. Coll. Sports Med. 2006, 38, 787-794. [CrossRef]

79. Koohsari, M.J.; Badland, H.; Sugiyama, T.; Mavoa, S.; Christian, H.; Giles-Corti, B. Mismatch between Perceived and Objectively Measured Land Use Mix and Street Connectivity: Associations with Neighborhood Walking. J. Urban Health 2015, 92, 242-252. [CrossRef]

80. Cerin, E.; Conway, T.L.; Adams, M.A.; Barnett, A.; Cain, K.L.; Owen, N.; Christiansen, L.B.; van Dyck, D.; Mitáš, J.; Sarmiento, O.L.; et al. Objectively-assessed neighbourhood destination accessibility and physical activity in adults from 10 countries: An analysis of moderators and perceptions as mediators. Soc. Sci. Med. 2018, 211, 282-293. [CrossRef]

81. Lee, E.; Dean, J. Perceptions of walkability and determinants of walking behaviour among urban seniors in Toronto, Canada. J. Transp. Health 2018, 9, 309-320. [CrossRef]

82. Shaw, C.; Russell, M. Benchmarking Cycling and Walking in Six New Zealand Cities; New Zealand Centre for Sustainable Cities, University of Otago: Wellington, New Zealand, 2016.

83. Witten, K.; Pearce, J.; Day, P. Neighbourhood Destination Accessibility Index: A GIS tool for measuring infrastructure support for neighbourhood physical activity. Environ. Plan. A 2011, 43, 205-223. [CrossRef]

84. Esteban-Cornejo, I.; Carlson, J.A.; Conway, T.L.; Cain, K.L.; Saelens, B.E.; Frank, L.D.; Glanz, K.; Roman, C.G.; Sallis, J.F. Parental and adolescent perceptions of neighbourhood safety related to adolescents' physical activity in their neighborhood. Res. Q. Exerc. Sport 2016, 87, 191-199. [CrossRef]

85. Hume, C.; Timperio, A.; Salmon, J.; Carver, A.; Giles-Corti, B.; Crawford, D. Walking and Cycling to School Predictors of Increases Among Children and Adolescents. Am. J. Prev. Med. 2009, 36, 195-200. [CrossRef]

86. Timperio, A.; Ball, K.; Salmon, J.; Roberts, R.; Giles-Corti, B.; Simmons, D.; Baur, L.A.; Crawford, D. Personal, Family, Social, and Environmental Correlates of Active Commuting to School. Am. J. Prev. Med. 2006, 30, 45-51. [CrossRef]

87. Witten, K.; Kearns, R.; Carroll, P.; Asiasiga, L.; Tava'e, N. New Zealand parents' understandings of the intergenerational decline in children's independent outdoor play and active travel. Child.'s Geogr. 2013, 11, 215-229. [CrossRef]

88. Environmental Health Indicators New Zealand. Number of Motor Vehicles in New Zealand. Available online: http://www.ehinz.ac.nz/assets/Factsheets/Released-2017/NumberOfVehiclesInNZ20002016-release201710.pdf (accessed on 15 March 2019).

89. Mitchell, C.A.; Clark, A.F.; Gilliland, J.A. Built environment influences of children's physical activity: Examining differences by neighbourhood size and sex. Int. J. Environ. Res. Public Health 2016, 13, 130. [CrossRef]

90. Hasanzadeh, K.; Laatikainen, T.; Kyttä, M. A place-based model of local activity spaces: Individual place exposure and characteristics. J. Geogr. Syst. 2018, 20, 227-252. [CrossRef]

(C) 2019 by the authors. Licensee MDPI, Basel, Switzerland. This article is an open access article distributed under the terms and conditions of the Creative Commons Attribution (CC BY) license (http://creativecommons.org/licenses/by/4.0/). 